\title{
Ecology and life history traits of the benthopelagic mysid Boreomysis oparva from the eastern tropical Pacific oxygen minimum zone
}

\author{
Jennifer Saltzman* \\ Graduate School of Oceanography, University of Rhode Island, Narragansett, Rhode Island 02882, USA
}

\begin{abstract}
The ecology and life history traits of Boreomysis oparva, a recently described benthopelagic mysid, were examined from the seamount Volcano 7 which penetrates into the oxygen minimum zone. In the near-bottom waters, $B$ oparva was very abundant at the lower summit in the oxygen minimum zone $\left(<0.2 \mathrm{ml} \mathrm{O}_{2} \mathrm{l}^{-1}\right)$. It decreased in abundance with increasing depth and increasing oxygen at the flank and was absent from the base of Volcano 7 . Length distribution of free-living stages was contunuous, from 4 to $26 \mathrm{~mm}$, and similar at the lower summit and flank. This and the presence of larvae of all stages suggest continuous rather than seasonal reproduction. Reproductive females with developing larvae were more abundant at the lower summit than the flank. This new oxygen minimum zone mysid has relationships of egg volume and clutch size to female body length similar to other mesoand bathypelagic mysids.
\end{abstract}

KEY WORDS: Life history traits - Oxygen minimum zone Deep-sea mysids - Boreomysis oparva . Seamounts

\section{INTRODUCTION}

Life history studies focus on co-adapted traits as tactics to solve ecological problems (Stearns 1976). Environmental factors affect the reproductive success of parents by influencing the fitness of offspring and, thus, the evolution of life history traits. Factors that limit the energy available to organisms have the greatest effect on life history traits and the distribution of energy between traits. Comparative studies within taxa allow for predictions to be made from trends of life history traits. For example, brood volume and body volume of oceanic pelagic crustaceans tend to be correlated with each other (Mauchline 1988). Since female mysids (Superorder Peracarida) have lamellae in which developing larvae are carried, it is possible to study some life history traits of deep-sea mysids. In Mysidacea, meso- and bathypelagic species have relatively fewer and larger eggs than shallower-living species (Mauchline 1973, 1980, Wittmann 1984). Also the

•E-mail: 103067.2421@compuserve.com egg size tends to remain a constant proportion of body size for all meso- and bathypelagic mysids. Life history traits of a species limited by oxygen have not previously been examined with respect to these trends.

Environmental characteristics, such as low temperature and high pressure, affect the physiology of animals in the deep sea. Shallow-living species generally respire at much higher rates than deeper-living species (Smith \& Hessler 1974, Childress 1975, 1977. Smith 1978, Torres et al. 1979) Mechanisms for lower energetic output through low metabolic rates include physiological and biochemical changes. Metabolic rates of deeper-living pelagic crustaceans and fishes generally vary as a function of depth, due primarily to temperature, pressure, and size (Childress \& Nygaard 1973). The bathypelagic mysid Gnathophausia ingens and a benthic scorpaenid fish show adaptations in blood oxygen affinity and heart metabolic enzymes for life in low-oxygen waters (Childress \& Price 1978, 1983, Sanders \& Childress 1990, Yang et al. 1992).

Midwater oxygen minimum zones (OMZs), which exist in all the world's oceans, are especially prominent in the eastern Atlantic off NW Africa, in the northern 
Indian Ocean and in the eastern tropical Pacific (Kamykowski \& Zentara 1990). In these regions, OMZs reach to about $1000 \mathrm{~m}$ depth and the oxygen concentration decreases to less than $0.2 \mathrm{ml} \mathrm{O}_{2} \mathrm{I}^{-1}$. The concentration of oxygen influences plankton distributions. species composition and species assemblages in the OMZ (Vinogradov \& Voronina 1962, Longhurst 1967, Brinton 1979, Weikert 1980, Saltzman 1995). At the lower interface of OMZs, biological and biogeochemical activities are elevated (Wishner et al. 1995)

The new mysid species Boreomysis oparva (Crustacea: Mysidacea) was discovered on a seamount in the eastern tropical Pacific (Saltzman \& Bowman 1993). This inactive seamount, Volcano 7, protrudes up into the prominent $\mathrm{OMZ}$. At the seamount summit, distinct faunal zones of the benthic and near-bottom communities appeared to be related to the oxygen concentration (Wishner et al. 1990, 1995, Levin et al. 1991). Between 750 and $770 \mathrm{~m}$, a physiological boundary, related to the oxygen gradient, separated communities. Above the boundary, benthic megafaunal abundances were low, although meiofauna and sediment bacteria abundances were high. Tens of meters below the boundary, the near-bottom zooplankton, including $B$. oparva, and benthic megafauna and macrofauna were more abundant than usual in the deep sea. This paper examines the ecology and life history traits of Boreomysis oparva in relation to the OMZ at Volcano 7.

\section{METHODS}

The study site, Volcano 7, rises from a depth of $3400 \mathrm{~m}$ to its summit at $730 \mathrm{~m}$. Zooplankton samples were collected in November 1988 from the submersible DSRV 'ALVIN' operated by the RV 'Atlantis II' at $13-14^{\circ} \mathrm{N}$, $102-103^{\circ} \mathrm{W}$. A total of 10 dives were made: 4 to the summit ( 724 to $908 \mathrm{~m}$ ), 3 to the flank (1162 to $1339 \mathrm{~m}$ ) and 3 to the base (2944 to $3112 \mathrm{~m}$ ) of the seamount.

Mysids were collected with a multiple opening-closing 8 net system modified for the submersible (Wishner \& Meise-Munns 1984, Wishner \& Gowing 1987) Nets of $183 \mu \mathrm{m}$ mesh, with mouth openings of $40 \times 40 \mathrm{~cm}$, were towed 1 to $5 \mathrm{~m}$ above the bottom. From the 8 net system, 4 sets of duplicate samples were collected during each dive. Three pairs of nets were open for about $15 \mathrm{~min}$, filtering 26 to $275 \mathrm{~m}^{3}$ of water (median of $73 \mathrm{~m}^{3}$ ) and trapping the mysids in the cod end for feeding experiments (details and results in Gowing \& Wishner 1992, Wishner \& Gowing 1992, Wishner et al. 1995) The fourth pair of nets was towed for approximately $1 \mathrm{~h}$ and filtered 90 to $347 \mathrm{~m}^{3}$ of water (median of $271 \mathrm{~m}^{3}$ ) for zooplankton abundance measurements. The specially designed cod ends were operated from the submersible and preserved the zooplankton in situ within the cod end when closed. Specimens were killed with MS-222 $\left(2 \mathrm{gl}^{-1}\right)$ in situ and preserved in $4 \%$ buffered formalin on board, or preserved in situ with glutaraldehyde. Mysids collected in the cod end and net were combined for all analyses.

In situ environmental parameters (temperature, conductivity, pressure, and time) were recorded with a Seacat CTD attached to the submersible. Dissolved oxygen in the near-bottom water of the seamount at each site was determined from water collected in Niskin bottles attached to the submersible. Oxygen concentration was measured by a modification of the Winkler titration method for low oxygen (Carritt \& Carpenter 1966). Particulate organic carbon (POC) in the water from the same bottles was determined with $\mathrm{CHN}$ measurements using a Carlo Erba 1106 Elemental Analyzer (Wishner et al. 1995). Time series measurements of temperature from moored current meters with temperature probes were described by Wishner ct al. (1995). In the water column above and around Volcano 7, temperature, salinity, and dissolved oxygen were measured with an SBE 19 Seacat CTD Profiler. Data from 31 CTD casts defined the physical structure of the water column, especially the extent of the $\mathrm{OMZ}$ (Wishner et al. 1990, 1995, Levin et al. 1991).

Abundance of Boreomysis oparva in each sample was determined from the total number of free-living mysids (defined as mature and immature individuals) collected in the cod end and the net. Damaged and partial specimens were included for abundance estimates. The ratio of females to males was determined using total counts of specimens with sexual traits (lamellae, the plate like process of the brood pouch, for females and developed pleopods for males).

The developmental stages (larvae) of mysids, which are carried by the females in their brood pouch, were not included in abundance calculations. Some larvae were found intact in female brood pouches. Most larvae were found free in the samples but had most likely been lost from the female's brood pouch during collection. Larvae were separated into 3 stages as defined by Jepsen (1965) and Mauchline (1980). Briefly, Stage I were egg-like, Stage II had yolk above the eyes, attached to the carapace, and Stage III had more developed legs and little yolk above the eyes. Gravid females were females observed with at least one larva intact in their brood pouches.

Body length was measured using the Zeus videobased image analysis system (Estep \& MacIntyre 1989). For free-living mysids, total length was measured from the tip of the rostrum to the end of the telson. The diameter for Stage I larvae and the total length for Stage II and Stage III larvae were measured. The lengths of specimens from several nets were not measured because they were either destroyed in analysis of feeding rates or gut 
contents, or were donated for taxonomic purposes. For 10 samples, mysids were videotaped before feeding rate analyses and the lengths of 66 specimens were measured from video tape images using the same system.

\section{RESULTS}

\section{Oxygen availability}

Oxygen concentration was less than $0.5 \mathrm{ml} \mathrm{O}_{2} \mathrm{l}^{-1}$ at median depths of 72 to $1302 \mathrm{~m}$ and less than $0.1 \mathrm{ml} \mathrm{O}_{2}$ $\mathrm{l}^{-1}$ at median depths of 288 to $1077 \mathrm{~m}$ (Fig 1). The minimum concentration of oxygen was found between 700 and $900 \mathrm{~m}$ and appeared to oscillate vertically over $30 \mathrm{~m}$, probably with a semi-diurnal tidal cycle (Levin et al. 1991, Wishner et al. 1995, L. S. Mullineaux unpubl.). The seamount summit protrudes into the OMZ. Nearbottom oxygen concentration on the seamount increased with increasing depth. However, tidal displacement of water passing over the seamount probably caused periodic variation in oxygen concentration at any particular site on the summit (Levin et al. 1991, Wishner et al. 1995). Temperature-depth and temperature-oxygen relationships in the pelagic realm were compared with time series temperature records on the seamount summit (from moored current meters). They revealed that benthopelagic fauna above $800 \mathrm{~m}$ were exposed to lower oxygen concentrations more often than those below $800 \mathrm{~m}$ (Wishner et al. 1995). At $830 \mathrm{~m}$, exposure to minimum oxygen was less than $0.1 \%$ over $9 \mathrm{~d}$, while at $730 \mathrm{~m}$, exposure to minimum oxygen occurred more than $65 \%$ of the time.

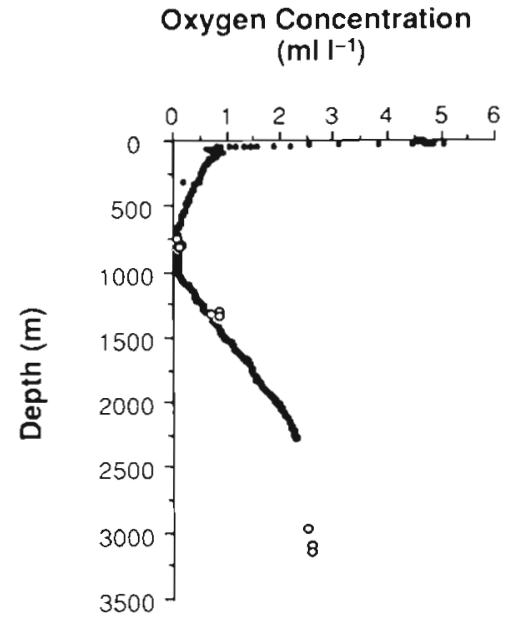

Fig. 1. Oxygen concentration in the near-bottom water (o) and in the pelagic realm (•) at Volcano $?$ Oxygen concentration from the near-bottom water was collected in Niskin bottles attached to the submersible. A constant of 0.124 was added to the calibrated oxygen values from 0 to $455 \mathrm{~m}$ of the pelagic CTD cast to correct for sensor offset

\section{Abundance and distribution}

No mysids were collected above $770 \mathrm{~m}$ in the leastoxygenated waters at the upper summit. Just below $770 \mathrm{~m}$, at 775 to $825 \mathrm{~m}$ on the lower summit, Boreomysis oparva was abundant (up to 114.3 per $100 \mathrm{~m}^{3}$ ) and was found in almost all samples (Fig. 2, Table 1). The oxygen concentration was slightly higher and POC was lower at the lower summit than at the upper summit (Saltzman 1995. Wishner et al. 1995). B. oparva was an order of

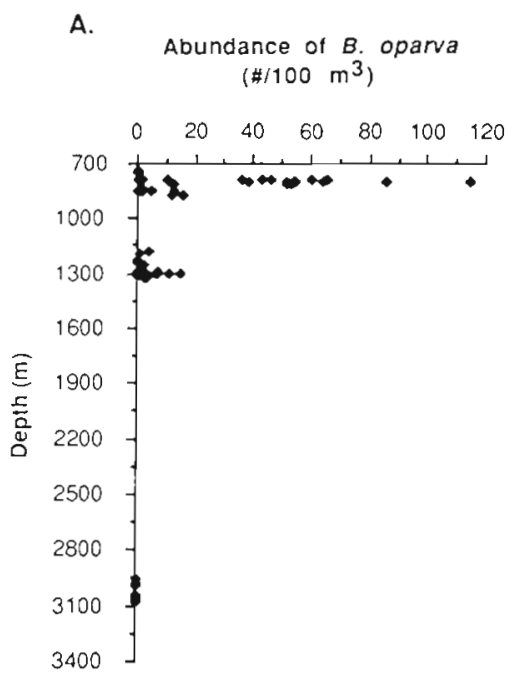

B.

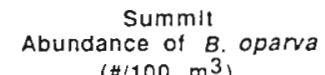
$\left(\# / 100 \mathrm{~m}^{3}\right)$

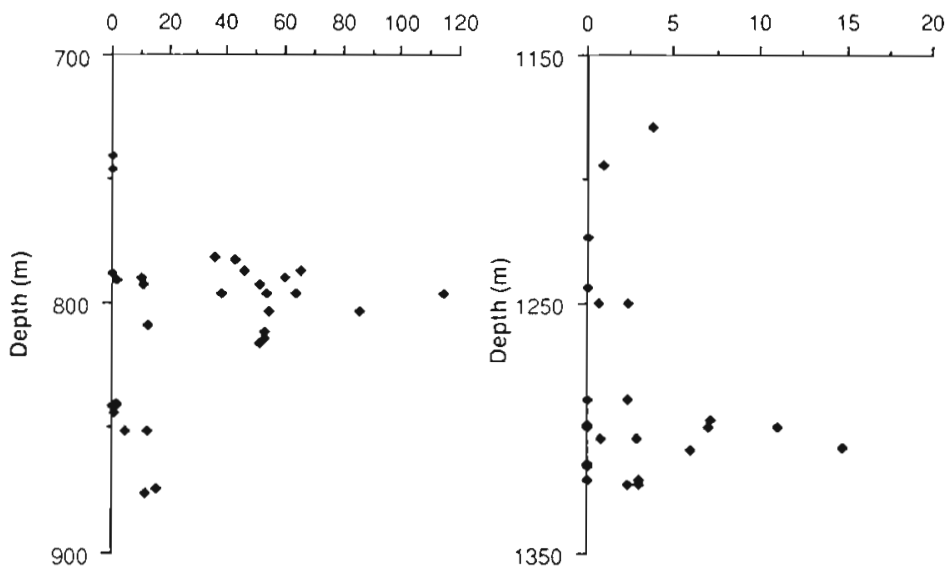

Fig. 2. Boreomysis oparva. Abundance in the near-bottom waters of Volcano 7 (ALVIN samples). (A) Depth range of entire seamount. (B) The summit area. (C) The flank area. Each symbol represents one sample, plotted at the middepth of the sampling interval, including samples with zero abundance of B. oparva. Abundance axes differ 
Table 1. Boreomysis oparva. Abundance and frequency of occurrence in the near-bottom waters of Volcano 7 Abundances are reported in number per $100 \mathrm{~m}^{3}$ 'With zeros' refers to the inclusion of zero abundance samples and 'without zeros' refers to the exclusion of these samples in calculating the mean abundance. Gender ratio and percent immature vere computed with the total number of males, female and immature at each depth zone. Immature mysıds were mysids without sexual traits, but not larvae

\begin{tabular}{|c|c|c|c|}
\hline & Lower summit & Flank & $\begin{array}{l}\text { Lower summit } \\
\text { \& flank }\end{array}$ \\
\hline Samples with B. oparva & 26 of 28 & 15 of 24 & 41 of 52 \\
\hline \multicolumn{4}{|l|}{$\%$ with $B$. oparva } \\
\hline Total & 93 & 63 & 78 \\
\hline Females & 75 & 33 & 56 \\
\hline \multicolumn{4}{|l|}{ Average abundance } \\
\hline Total, with zeros & $34.1 \pm 30.0$ & $2.8 \pm 3.9$ & $19.6 \pm 27.1$ \\
\hline Total, without zeros & $36.7 \pm 29.6$ & $4.5 \pm 4.0$ & $24.9 \pm 28.3$ \\
\hline Females, with zeros & $10.3 \pm 10.4$ & $0.6 \pm 1.2$ & $5.8 \pm 9.0$ \\
\hline \multicolumn{4}{|l|}{ Median abundance } \\
\hline With zeros & 36.8 & 1.6 & 5.4 \\
\hline Without zeros & 40.4 & 3 & 11.2 \\
\hline Maximum abundance & 114.3 & 14.8 & 114.3 \\
\hline \multicolumn{4}{|c|}{ Gender and stage distribution } \\
\hline Female:male ratio & 2.8 & 1.7 & 2.7 \\
\hline Percent immature & 64 & 72 & 65 \\
\hline
\end{tabular}

magnitude less abundant and less frequently found at the flank (1163 to $1332 \mathrm{~m}$ ) than at the lower summit (Table 1). No mysids were collected near the base $(2900$ to $3200 \mathrm{~m}$ ) of the seamount, where maximum oxygen concentrations and minimum POC occurred.

Abundances of Boreomysis oparva were not significantly different in samples collected simultaneously in paired nets. The abundance difference between paired samples was the same for both $15 \mathrm{~min}$ tows and
$1 \mathrm{~h}$ tows ( $t$-test, $\mathrm{p}<0.05$ ). The abundance differences between paired samples were greater at the lower summit (18.2 \pm 20.5 per $\left.100 \mathrm{~m}^{3}\right)$ than at the flank $(4.0 \pm 3.6$ per $100 \mathrm{~m}^{3}$ ) (Mann-Whitney $U$-test. $\mathrm{p}<0.05$ )

Two other Boreomysis species occurred in the near-bottom water at the lower summit (Table 2). Sixteen specimens of $B$. californica and 1 specimen of an unidentified Boreomysis sp. were collected in 1 sample. B. oparva was less abundant than $B$. californica in this sample. In the paired sample collected at the same time, only $B$. oparva was found. In this single species sample, B. oparva $\left(12.7\right.$ per $\left.100 \mathrm{~m}^{3}\right)$ was only slightly more abundant than in the sample with both $B$. oparva and $B$. californica $\left(11.6\right.$ per $\left.100 \mathrm{~m}^{3}\right)$.

At both the lower summit and the flank, female Boreomysis oparva outnumbered the males with female:male ratios of 2.8 and 1.7 respectively (Table 1 ). Overall, $65 \%$ of the specimens were immature and their gender could not be determined; these were not included in the sex ratio.

\section{Length distribution}

Free-living Boreomysis oparva ranged in total length from about 4 to $25.9 \mathrm{~mm}$. The 3 largest specimens were mature males. Length distribution of freeliving $B$ oparva did not show separation of size classes (Fig. 3A). Frequency of length categories was evenly distributed for mid-sized mysids of 10 to $20 \mathrm{~mm}$ at the

Table 2. Boreomysis species other than Boreomysis oparva that were collected on and around Volcano 7 The near-bottom sample from an ALVIN tow also contained B. oparva. Pelagic samples were collected with a MOCNESS above the flank of Volcano 7 (methods in Saltzman 1995)

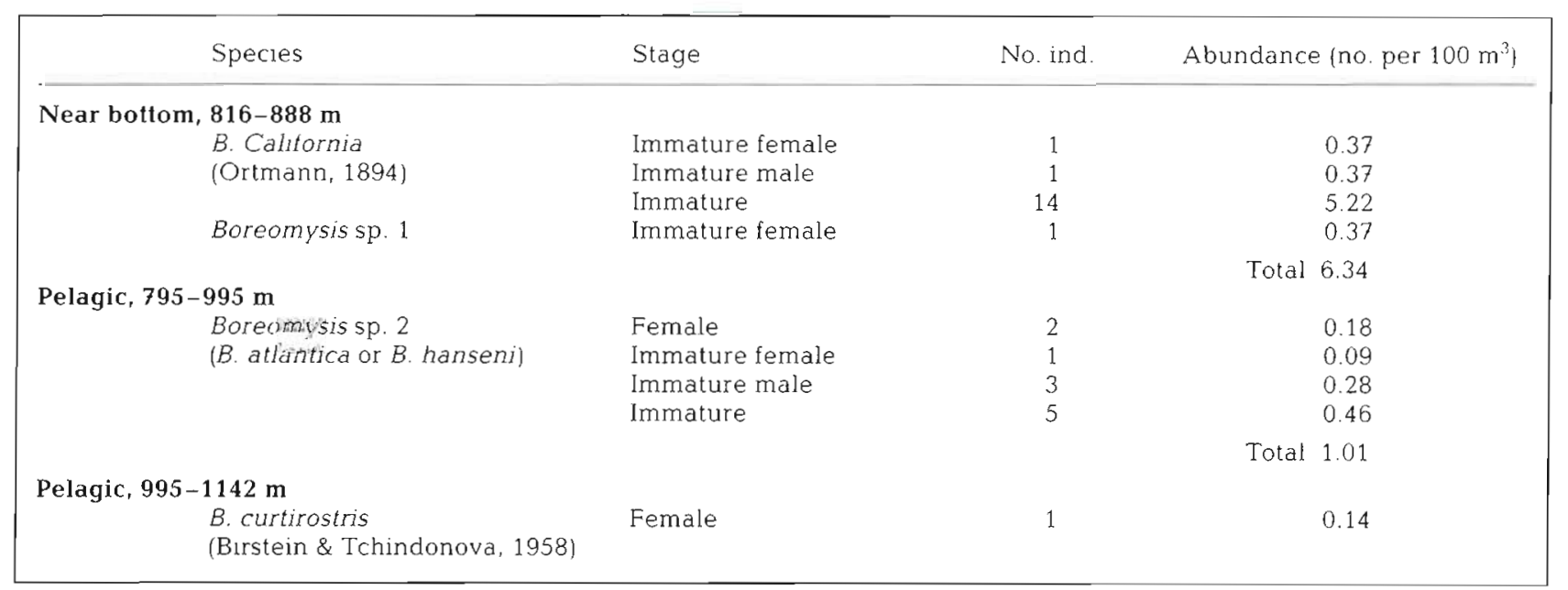


A. Length Distribution of B. oparva
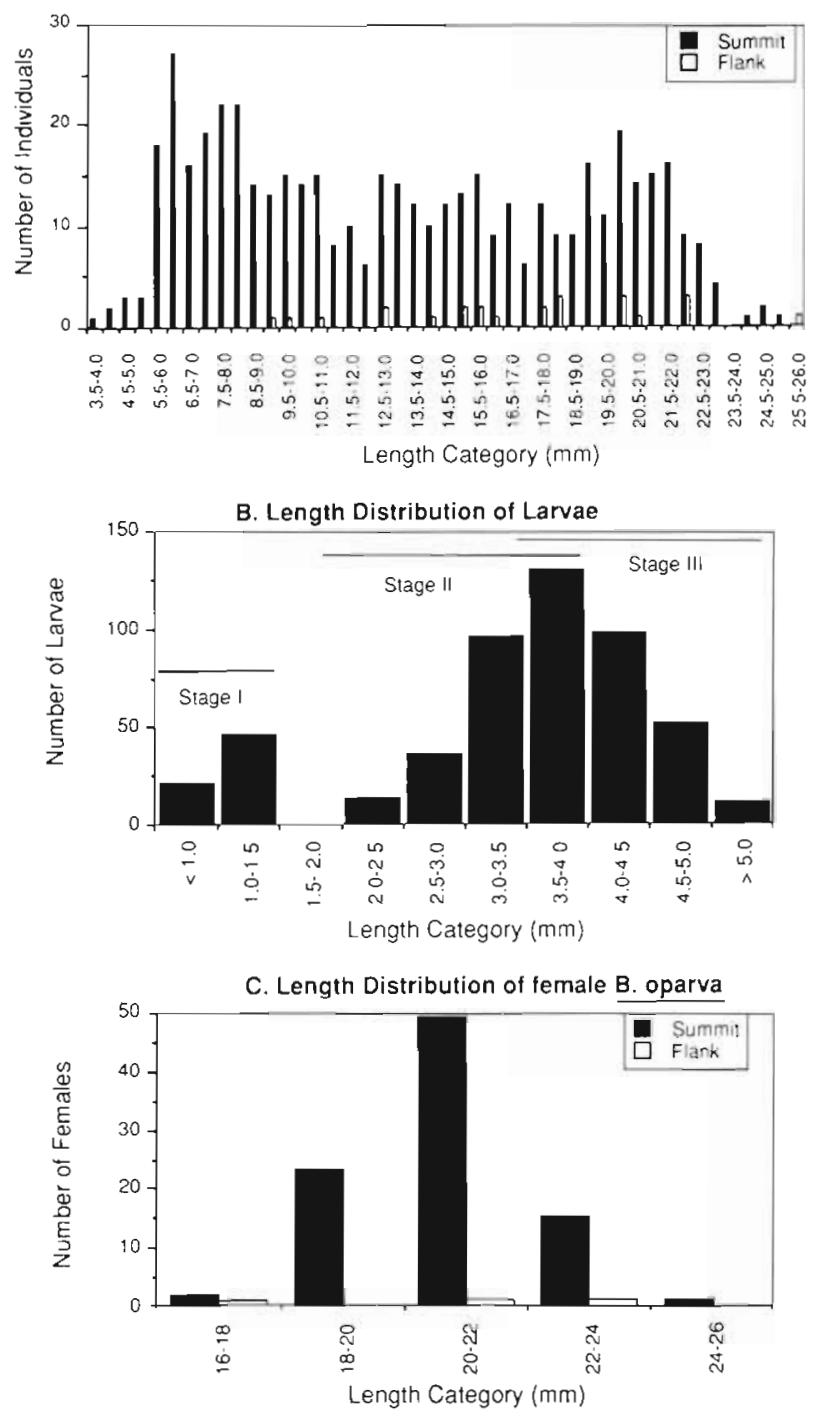

Fig. 3. Boreomysis oparva. Length distribution in the nearbottom waters of Volcano 7 (A) Free-living mysids at the summit and flank (523 mysids). Each interval is $0.5 \mathrm{~mm}$. (B) Larval mysids at the summit and flank areas combined (67 Stage I, 435 Stage II and Stage IIl). (C) Female mysids, with and without larvae in their brood pouches, at the summit and flank (91 females)

lower summit, suggesting continuous growth and reproduction. Evidence of even distribution was not as strong at the flank. This was the result of a smaller sample at the flank. Smaller size categories were less common at the flank.

Larvae (all stages) ranged in size from 0.8 to $5 \mathrm{~mm}$. The Stage I larvae ranged in size from 0.82 to $1.61 \mathrm{~mm}$ (Fig. 3B). The low frequency of larvae in the 1.5 to $2.0 \mathrm{~mm}$ range was due to round Stage I larvae developing laterally rather than spherically into Stage II larvae. Stages II and III overlapped in the 3.5 to
$4.0 \mathrm{~mm}$ size class. Larvae are probably released as free-living mysids at 4 to $5 \mathrm{~mm}$. A comparison between the lower summit and flank is not presented because a total of only 7 larvae was collected at the flank.

Females began to show lamellae when longer than $16 \mathrm{~mm}$ (Fig. 3C). The mean length of all females was $20.6 \pm 1.5 \mathrm{~mm}$. Females made up $72 \%$ of the mysids in the 20 to $22 \mathrm{~mm}$ class. Twelve females from the lower summit were observed carrying larvae. The mean length of a gravid female $(20.3 \pm 1.5 \mathrm{~mm})$ was nearly the same as for all females.

\section{Reproductive life history traits}

Boreomysis oparva were members of a reproducing population. At the lower summit, $7 \%$ of the females were observed with larvae in their brood pouches. Each gravid female had only 1 stage of larva, and all 3 stages of larvae were found in brood pouches and free in the samples. The mean observed clutch size of females with greater than 3 larvae was 8.5 larvae per female with a range of 5 to 12 larvae per female. The maximum observed clutch size was 12 Stage II larvae in a $23.29 \mathrm{~mm}$ female. The smallest mysid observed with a clutch was $18.13 \mathrm{~mm}$ and had 7 Stage III larvae. At the flank, none of the females were gravid.

\section{DISCUSSION}

Volcano 7 penetrates into the $\mathrm{OMZ}$ of the eastern tropical Pacific. At the summit, between 750 and $770 \mathrm{~m}$, it has been hypothesized that a physiological boundary separates the zooplankton communities; the upper and lower summit both had coarse-grained sediments, organic matter availability was high and constant, and oxygen concentration increased only slightly across the boundary (Wishner et al. 1990, 1995, Levin et al. 1991). The vertical distribution of the new species Boreomysis oparva was from slightly deeper than the region of the physiological boundary downslope to the flank, from about $770 \mathrm{~m}$ to at least $1340 \mathrm{~m}$ (but above $3000 \mathrm{~m}$ ). The vertical distributions of most mysid species are unknown (Mauchline \& Murano 1977).

Population characteristics of Boreomysis oparva changed downslope. Abundances were higher at the lower summit, associated with the lower OMZ interface, than at the flank. In addition, reproductive strategies (i.e. sex ratio, clutch size) appeared to differ between animals at the lower summit and flank. These differences may be related to the distance from the lower OMZ interface, oxygen concentration and fluc- 
tuation, near-bottom current strength related to bottom type, and sample size.

At the lower OMZ interface zone (600 to $800 \mathrm{~m}$ ), pelagic zooplankton abundances increased (Saltzman 1995). A narrow, particle-rich and carbon-rich pelagic layer occurred there (Wishner et al. 1995). Gut contents of Boreomysis oparva and other abundant detritivores suggested ingestion of bacterial aggregates, possibly formed in a layer or mat associated with the chemical gradients at this depth zone (Gowing \& Wishner 1992, Wishner et al. 1995) Also, sediment texture and composition suggested that the summit received high fluxes of relatively fresh organic matter (Levin et al. 1991). In contrast, organic matter values were low on the flank. Mysids appear to have a strong capability for adapting reproduction to ambient food levels (Wittmann 1984), which may explain the increased proportion of gravid females and larger clutch size at the lower summit in comparison to the flank.

The upper boundary of the distribution of Boreomysis oparva and other near-bottom zooplankton and macrofauna appeared to be related to the oxygen concentration (Wishner et al. 1990, 1995), which increased downslope. To survive in the low-oxygen environment, animals need low metabolic rates, mechanisms to extract oxygen at low concentrations, and/or the ability to use anaerobic metabolism for short periods. The bathypelagic mysid Gnathophausia ingens, which spends much of its life in the OMZ, has been extensively studied with respect to its low metabolic rate and ability to aerobically metabolize (Childress \& Price 1978, 1983) Seven midwater crustaceans, including Boreomysis californica, can survive anaerobically when oxygen is reduced to unmeasurable levels in the laboratory (Childress 1975). This may be important for B. oparva, because individuals at the lower summit are probably exposed to minimum oxygen concentrations for periods of time as a result of tidal displacement. $B$. californica and species of the genus Gnathophausia also have lower weight-specific respiration rates compared to other mysids (Childress 1971, 1975, Mauchline 1980).

Differences in abundances at the lower summit and flank may also be due to differences in terrain. The terrain at the summit was a mixture of sedimented and rocky areas; the flank was mostly rocky. The strongest and most persistent currents were at the flank (Levin et al. 1991). Visual observations suggested that Boreomysis oparva was distributed in patches over sediment flats and occurred at particular altitudes, especially within the bottom meter or two (K. F. Wishner pers. comm.). They were not observed over the rocky outcrops, but possibly occurred over the mixed sediment areas with rocks and sand.
Mysids often live in aggregations, some as breeding aggregations and others as schools, during certain periods of their life cycles (Mauchline 1980). Because each sample was taken over a variety of microenvironments (altitude, slope, substrate type), it was not possible to determine any preference from these samples
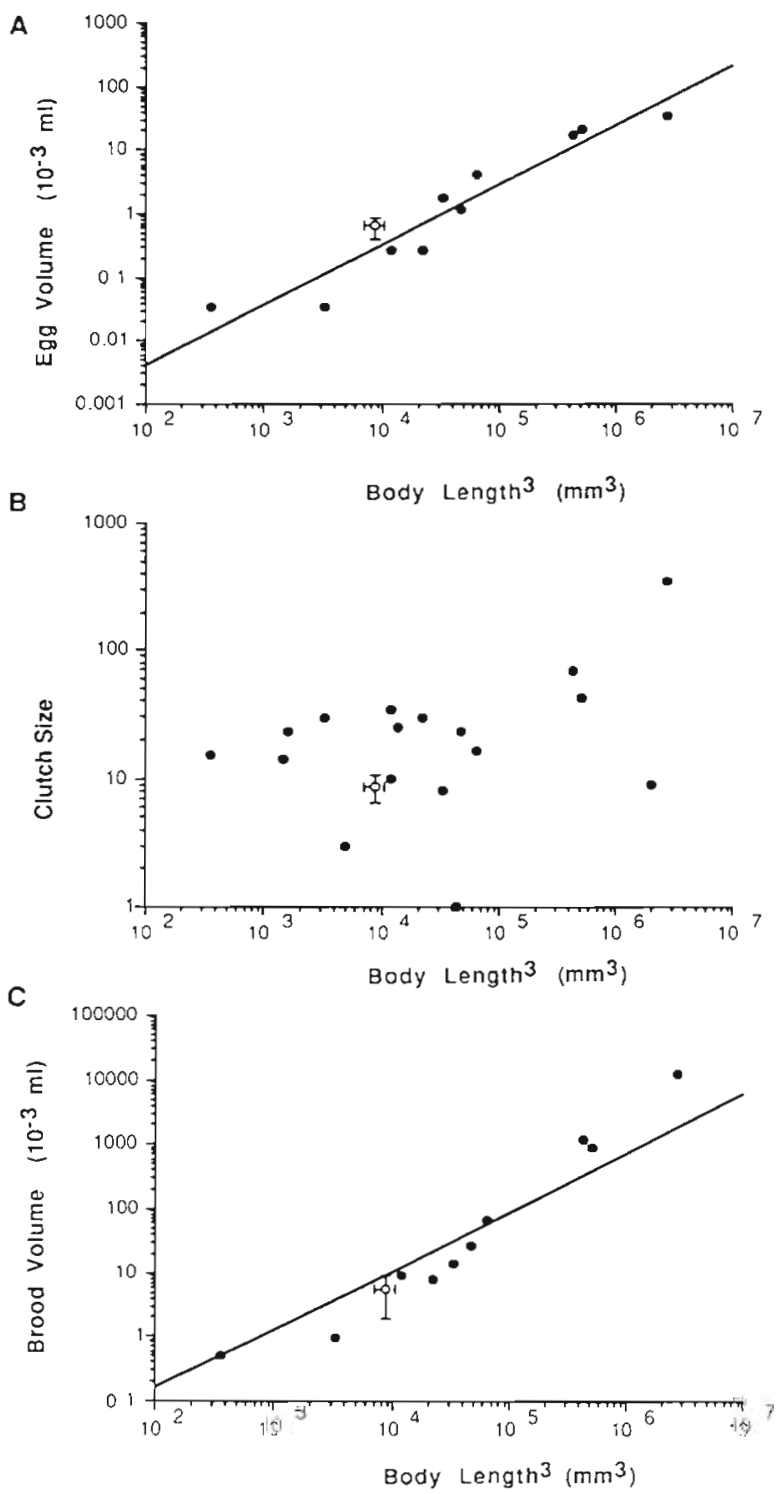

Fig. 4. Boreomysis oparva. The relationshup between total average body length (raised to the third power) of females and (A) average egg volume, (B) average clutch size and (C) brood volume: (-) from averages of observed meso- and bathypelagic mysids (Mauchline 1973, 1980); (0) the observed mean of $B$ oparva with error bars. firror bars represent the average difference between calculated value of the mean \pm 1 SD deviation of the observed values. Regression lines are from equations reported by Mauchline (1980), based on species where greater than 100 broods were observed and averaged for each species individually. Egg volume is the volume of an average Stage I larva, assuming a spherical shape 
The variation in abundance between simultaneously collecting nets may be explained in several ways. (1) Mysids which were distributed in small groups or swarms may have very specific altitude and/or substrate preferences. (2) Patches may be smaller than the distance between nets and distributed unevenly. (3) The submersible often traversed steep slopes, with the inboard net close to the bottom and the outboard net farther away, causing the samples to be collected from different altitudes.

\section{Reproductive life history trait comparisons}

Comparisons of reproductive traits of mysids have been made in several studies (Mauchline 1973, 1980 1988, Wittmann 1984, Clark \& Threlfall 1993). The relationship between egg volume and body length for Boreomysis oparva appears to fit the relationship found by Mauchline (1980) for meso- and bathypelagic mysids (Fig 4A). There appears to be a minimum size of egg, which seems to influence the size at emergence from the female brood pouch (Mauchline 1980). Postemergence larvae are unable to swim until they molt and may be subject to predation or cannibalism. This molt takes place within hours of emergence (Mauchline 1980). Thus, it is likely that there is a minimum viable size of emerging larvae (Mauchline 1988).

Clutch size is another ecologically important life history trait. The observed clutch size in relation to body length of Boreomysis oparva was compared with that of other meso- and bathypelagic mysids (Fig 4B). The regression coefficient was not significant for meso- and bathypelagic species ( $r=0.39$ ) (Mauchline 1973), yet $B$. oparva seems to fit with other observations. Observed clutch size in all meso- and bathypelagic mysids is a conservative estimate since loss of larvae is quite common.

Brood pouches of Mysidacea are made of 2, 3, or 7 overlapping pairs of lamellae attached to their thoracic legs. Species of the sub-order Lophogastrida and several genera of the sub-order Mysida, including Boreomysis, have 7 pairs of lamellae. The Lophogastrida include many meso- and bathypelagic species. Seven lamellae as opposed to 2 or 3 may provide more volume for developing larvae, yet larvae may be more easily lost. Loss of larvae from the brood pouch is not just a sampling concern, but a real problem for gravid females. Behavioral patterns show that females provide care to the larvae. Lateral movement of the lamellae in a rhythmic manner provides oxygen to the larvae (Mauchline 1980). This behavior probably causes accidental loss of larvae. Females have been observed in the laboratory replacing or 'adopting' lost larvae back into their brood pouch (Mauchline 1980, Wittmann 1984). In natural populations, females have been observed with 'adopted' larvae in their brood pouches (Wittmann 1978).

Brood volume, the product of clutch size and egg volume, is also directly related to body length, raised to the third power, for all epi-, meso- and bathypelagic mysids (Mauchline 1973, 1980). From these comparisons, Boreomysis oparva, a benthopelagic mysid, looks like a typical mesopelagic species (Fig. 4). Oxygen limitation does not appear to disrupt the general relationships between these life history traits

Life history traits of Boreomysis oparva are similar to those of other Boreomysis species (Table 3). B. oparva has smaller Stage I larvae but larger Stage III larvae than $B$. tridens, a bathypelagic species. Growth rate or minimum viable size at emergence may be reasons for this difference. The clutch is considerably smaller for $B$. oparva than for most other Boreomysis species reported. Clark \& Threlfall (1993) reported that $B$. nobilis, a cold-water near-bottom species, has a larger brood volume and egg volume in relation to its body volume than expected for epipelagic and coastal mysids from Mauchline's (1980) relationships. They suggested that this is because egg size is related to temperature (Wittmann 1984). B. oparva from 3.5 to

Table 3 . Lite history tratts of Boreomysis spp. (as mean \pm SE or range). For Boreomysls oparva, observed clutch size is reported and range of lengths is included in parentheses. Data for other species compiled by Mauchline $(1973,1980,1986)$ and Clark \& Threlfall (1993)

\begin{tabular}{|c|c|c|c|c|c|}
\hline Species & $\begin{array}{l}\text { Body length of } \\
\text { female }(\mathrm{mm})\end{array}$ & $\begin{array}{c}\text { Range of clutch size } \\
\text { (larvae/female) }\end{array}$ & $\begin{array}{c}\text { Stage I } \\
\text { length (mm) }\end{array}$ & $\begin{array}{c}\text { Stage II } \\
\text { length }(\mathrm{mm})\end{array}$ & $\begin{array}{c}\text { Stage IIl } \\
\text { length (mm) }\end{array}$ \\
\hline Boreomysis oparva & $\begin{array}{l}20.6 \pm 1.5 \\
(17.2-24.3)\end{array}$ & $5-12$ & $\begin{array}{c}1.1 \pm 0.1 \\
(0.8-1.6)\end{array}$ & $\begin{array}{c}3.5 \pm 0.5 \\
(2.0-4.5)\end{array}$ & $\begin{array}{l}4.4 \pm 0.5 \\
(2.3-5.6)\end{array}$ \\
\hline B. arctica & $20-28$ & $3-44$ & $0.8=1.1$ & & 3.9 \\
\hline B. megalops & 17 & 3 & & & \\
\hline B. microps & $15-20$ & $9-18$ & $0.7-0.8$ & & \\
\hline B. nobilis & $35.1 \pm 1.6$ & $\sim 20-25$ & $1.6 \pm 0.1$ & & $\sim 7.5-8.0$ \\
\hline B. tridens & $20-28$ & $27-35$ & $1.9-2.1$ & & $3.8-3.9$ \\
\hline
\end{tabular}


$5.7^{\circ} \mathrm{C}$ water had smaller larvae than $B$. nobilis from -1.3 to $2.2^{\circ} \mathrm{C}$ water. The trend in temperature-size differences between these 2 species is consistent with the relationship described by Wittmann (1984).

\section{New species remarks}

Finding a new species at Volcano 7 is not surprising because near-bottom deep-sea zooplankton have not been well studied in general and especially not on seamounts (Kaufmann et al. 1989). Furthermore, the high percentage of endemic species suggests that seamounts are sites with a high incidence of speciation (Wilson \& Kaufmann 1987, Rogers 1994). Seamounts may enhance speciation through isolation (Wilson \& Kaufmann 1987) or may act as stepping stones for dispersal (Hamilton 1956, Newman 1986)

All the Mysidacea found in the Volcano 7 area were Boreomysis spp. In the benthopelagic zone, there were a total of 3 species of Boreomysis and, in the pelagic zone, there were 2 additional species (Table 2). Many Boreomysis spp. are considered meso- or bathypelagic from pelagic sampling, though most species of Mysidacea live in close association with the ocean bottom (Fösa 1985, Kaartvedt 1985) One of the important morphological features of Boreomysis is 7 pairs of lamellae in the females. Since larvae are provided with oxygen by the female moving the lamellae, Boreomysis spp., or other genera with 7 pairs of lamellae, may be able to provide more oxygen to their larvae. This is especially important for species living within the oxygen minimum zone.

Acknowledgements. I thank all the scientists, the captain, and the crew who participated and helped in this cruise. Thank you to $K$. F. Wishner for providing the specimens for analysis and reviewing this manuscript and to C. J. Ashjaan for teaching me to use the Zeus system. This work was funded in part by NSF grants OCE-8608846, OCE-8716564, and OCE8720193

\section{LITERATURE CITED}

Brinton E (1979) Parameters relating to the distributions of planktonic organisms, especially Euphausiids in the eastern tropical Pacific. Prog Oceanogr 8:125-189

Carritt DE, Carpenter JH (1966) Comparison and evaluation of currently employed modifications of the Winkler method for determining dissolved oxygen in seawater; a NASCO report. J Mar Res 24:286-318

Childress JJ (1971) Respiratory rate and depth of occurrence of midwater animals. Limnol Oceanogr 16:104-106

Childress JJ (1975) The respiratory rates of midwater crustaceans as a function of depth of occurrence and relation to the oxygen minimum layer off southern California. Comp Biochem Physiol 50A:787-799

Childress JJ (1977) Effects of pressure, temperature and oxygen on the oxygen consumption rate of the midwater copepod Gaussia princeps. Mar Biol 39:19-24

Childress JJ, Nygaard MH (1973) The chemical composition of midwater fishes as a function of depth of occurrence off Southern California. Deep Sea Res 20:1093-1109

Childress JJ, Price MH (1978) Growth rate of the bathypelagic crustacean Gnathophausia ingens (Mysidacea: Lophogastridae). I. Dimensional growth and population structure. Mar Biol 50:47-62

Childress JJ, Price MH (1983) Growth rate of the bathypelagic crustacean Gnathophausıa ingens (Mysidacea: Lophogastridae) II. Accumulation of material and energy. Mar Biol $76: 165-177$

Clark KJ, Threlfall W (1993) The geographical distribution, population dynamics and reproductive biology of Boreomysis nobils in Newfoundland tjords. J Mar Biol Ass UK 73: $755-768$

Estep KW, MacIntyre F (1989) Counting, sizıng, and identification of algae using image analysis. Sarsia 74:261-268

Fössa JH (1985) Near-bottom vertical zonation during daytime of deep-living hyperbenthic mysids (Crustacea Mysidacea). Sarsia 70:297-307

Gowing MM, Wishner KF (1992) Feeding ecology of benthopelagic zooplankton on an eastern tropical pacific seamount. Mar Biol 112:451-467

Hamilton EL (1956) Sunken islands of the Mid-Pacific Mountains. Geo Soc Am Mem 64:1-97

Jepsen I (1965) Marsupial development of Boreomysis artica (Kröyer, 1861). Sarsia 20:1-8

Kaartvedt S (1985) Diel changes in small-scale vertical distribution of hyperbenthic mysids. Sarsia 70:287-295

Kamykowski D, Zentara S (1990) Hypoxia in the world ocean as recorded in the historical data set. Deep Sea Res 37 . $1861-1874$

Kaufmann RS, Wakefield WW, Genin A (1989) Distribution of epibenthic megafauna and lebensspuren on two central North Pacific seamounts. Deep Sea Res 36:1863-1896

Levin LA, Huggett CL, Wishner KF (1991) Control of deep-sea benthic community structure of oxygen and organic-matter gradients in the eastern Pacific Ocean. J Mar Res 49: $763-800$

Longhurst AR (1967) Vertical distribution of zooplankton in relation to the eastern Pacific oxygen minimum. Deep Sea Res 14:51-63

Mauchline J (1973) The broods of British Mysidacea (Crustacea). J Mar Biol Ass UK 53:801-817

Mauchline J (1980) The biology of mysids and euphausiids. Adv Mar Biol 18:1-369

Mauchline J (1986) The blology of the deep-sea species of Mysidacea (Crustacea) of the Rockall Trough. J Mar Biol Ass UK 66:803-824

Mauchlıne J (1988) Egg and brood sizes of oceanic pelagic crustaceans. Mar Ecol Prog Ser 43:251-258

Mauchline J, Murano M (1977) World list of the Mysidacea, Crustacea. J Tokyo Univ Fish 64:39-88

Newman WA (1986) Origin of the Hawanan marine fauna: dispersal and vicariance as indicated by barnacles and other organisms. Crustacean Issues 4.21-49

Rogers AD (1994) The biology of seamounts. Adv Mar Biol 30: $305-350$

Saltzman J (1995) Zooplankton ecology in relation to a promınent oxygen minimum zone and a seamount in the eastern tropical Pacific. Doctoral dissertation, University of Rhode Island, Kingston

Saltzman J, Bowman TE (1993) Boreomysis oparva, a new possum shrump (Crustacea: Mysidacea) from an eastern tropical Pacific seamount. Proc Biol Soc Wash 106 . $325-331$ 
Sanders NK, Chuldress JJ (1990) Adaptations to the deep-sea oxygen minimum layer: oxygen binding by the hemocyanin of the bathypelagic mysid, Gnathophausia ingens Dohrn. Biol Bull 178:286-294

Smith KL (1978) Metabolism of the abyssopelagic rattail Coryphaenoides armatus measured in situ. Nature 274: $362-364$

Smith KL, Hessler RR (1974) Resprration of benthopelagic fishes: in situ measurements at $1230 \mathrm{~m}$. Science 184:72-73

Stearns SC (1976) Life-history tactics: a review of the ideas. Q Rev Biol 51:3-47

Torres JJ, Belman BW, Childress JJ (1979) Oxygen consumption rates of midwater fishes as a function of depth of occurrence. Deep Sea Res 26:185-197

Vinogradov ME, Voronina NM (1962) Influence of the oxygen deficit on the distribution of plankton in the Arabian Sea. Deep Sea Res 9:525-530 (orignal work in Okeanologia $1961,1: 670-678$ )

Weikert $H$ (1980) The oxygen minimum layer in the Red Sea: ecological implications of the zooplankton occurrence in the area of the Atlantis II Deep. Meeresforsch $28: 1-9$

Wilson RR, Kaufmann RS (1987) Seamount brota and biogeography. In: Keating BH, Fryer P, Batiza R, Boehlert GW (eds) Seamounts, islands and atolls. Geophys Monogr 43. Amerıcan Geophysical Unıon, Washington, DC, p 355-378 Wishner KF, Ashjian CJ, Gelfman C, Gowing MM, Kann L,

This article was submitted to the editor
Levin LA, Mullineaux LS, Saltzman J (1995) Pelagıc and benthic ecology of the lower interface of the eastern tropucal Pacific oxygen minimum zone. Deep Sea Res 41: 93-115

Wishner KF, Gowing MM (1987) In situ filternng and ingestion rates of deep-sea benthic boundary-layer zooplankton in the Santa Catalina Basin. Mar Biol 94:357-366

Wishner KF, Gowing MM (1992) The role of deep-sea zooplankton in carbon cycles. In: Rowe GT, Pariente $V$ (eds) Deep-sea food chains and the global carbon cycle. Kluwer Academic Publishers, Dordrecht, p 29-43

Wishner K, Levin L, Gowing M, Mullineaux L (1990) Multiple roles of the oxygen minimum in benthic zonation on a deep seamount. Nature 346:57-59

Wishner KF, Meise-Munns CJ (1984) In situ grazing rates of deep-sea benthic boundary-layer zooplankton. Mar Biol $84: 65-74$

Wittmann KJ (1978) Adoption, replacement and identification of young in marine Mysidacea (Crustacea). J Exp Mar Biol Ecol 32:259-274

Wittmann KJ (1984) Ecophysiology of marsupial development and reproduction in Mysidacea (Crustacea). Oceanogr Mar Biol A Rev 22:393-428

Yang TH, Lai NC, Graham JB, Somero GN (1992) Respiratory, blood, and heart enzymatic adaptations of Sebastolobus alascanus (Scorpaenidae: Teleostei) to the oxygen minimum zone: a comparative study. Biol Bull 183:490-499

Manuscript first recelved: October 10,1995

Revised version accepted: March 4, 1996 